\title{
Housework Division and Perceived Fairness: The Importance of Comparison Referents
}

\author{
by Renzo Carriero and Lorenzo Todesco \\ University of Turin; University of Turin \\ Sociological Research Online, 21 (1), 9 \\ <http://www.socresonline.org.uk/21/1/9.html> \\ DOI: $10.5153 /$ sro.3871
}

Received: 19 Oct 2015 | Accepted: 27 Jan 2016 I Published: 28 Feb 2016

\begin{abstract}
A long-standing theoretical tradition underlines the importance of comparison referents for fairness evaluation, i.e., people, experiences and expectations that individuals choose to compare with their own situation. However, few studies on perceived fairness of housework division have measured and tested comparison referents, partly because of the lack of suitable data. Moreover, findings were sometimes mixed because small convenience samples were used. Previous literature also neglected the distortive effects of selfserving bias in the choice of referents. This study, conducted in an Italian context, seeks to overcome these limitations by using a probabilistic sample and two different designs: a survey data analysis and an experimental-vignette technique which avoids the distortions of self-serving bias. The survey's findings reveal that the effects of comparison referents are strong and in line with expectations, though limited to the domestic behavior of male referents. Moreover, unfavorable comparisons have a stronger effect on perceived fairness than favorable ones. The vignette analysis indicates that comparison referents affect perceived housework fairness even if the effect of self-serving bias is controlled for.
\end{abstract}

Keywords: Comparison Referents, Perceived Fairness, Housework, Vignettes, Household Labor, Cognitive Dissonance Reduction

1.1 In the last twenty years, the issue of housework fairness has increasingly captured scholarly attention (Greenstein 1996; Layte 1998; Mikula 1998; Nordenmark \& Nyman 2003; Braun et al. 2008; Perales et al. 2015). The fact that most women and men still find an unequal division of domestic labor to be fair is considered one of the reasons for the different pace at which transformations in women's labor market participation (quite fast) and change in the distribution of unpaid family work (very slow) have proceeded (Öun 2013). Thus, housework fairness is not only relevant per se; it also contributes to explaining gender inequality in the division of household labor, which is a major obstacle for women's career opportunities (Charles \& Grusky 2004).

As regards the fairness evaluation process, for several decades sociologists and social psychologists have stressed the importance of comparison referents, i.e., people, experiences and expectations that individuals choose to compare with their own situation (Runciman 1966; Merton \& Rossi 1968). However, there have been few studies of the effect of comparison referents on housework fairness, partly because of the lack of suitable data. Moreover, almost all of the studies on comparison referents carried out so far were based on small convenience samples, which make generalization impossible. Another limitation of previous research is that the distortive effect of self-serving bias has been neglected: people often use comparison referents not for authentic reasons of self-evaluation, but rather to confirm and reinforce a positive view of their own situation, to avoid feelings of injustice, guilt and cognitive dissonance.

This study seeks to improve current knowledge by using survey data from a probability sample and an experimental-vignette technique that does not allow people to pick and choose between comparison referents for confirmative reasons. Two research questions are tackled here: 1) Does comparison referents' domestic behavior affect housework fairness? 2) If so, is this a genuine effect, or is it due to a self-serving bias?

Italy is an interesting context for our research. The country's welfare system is characterized in many respects by the so-called 'familialism by default' (Saraceno 2010): the state does not provide families with much support in meeting their care needs, which are mainly satisfied thanks to female unpaid work. Thus, social expectations push women to engage in these tasks. This situation is the cause and effect of a traditional cultural context which still considers home and children as primary duties for women, to the detriment of their working career (Lopez-Claros \& Zahidi 2005; Plantenga et al. 2009). Not surprisingly, dual-earner couples are less common in Italy than in most European countries (Eurostat 2015; see Labor Force Survey). Given Italy's conservative orientation and relatively low number of dual-earner couples, people in this non-traditional family arrangement are those who might have the greatest need to know the 'right' way of dividing domestic work. For 
The article is organized as follows. The first section addresses the topic of the study by detailing the theoretical framework and providing a summary of the available empirical evidence. The second section presents the motivation of the study. At the end of this section, we put forward two hypotheses to be tested in the rest of the study. The third section provides information on the research design and the sample. The fourth section details data and method of the survey analysis and presents its main findings. The fifth section does the same for the experimental-vignette analysis. The final section discusses the implications of the findings of both analyses.

\section{Theoretical and Empirical Background}

2.1 Since the middle of the last century, the concepts of relative deprivation and social comparison have been associated with the perception of fairness and justice. Both relative deprivation and social comparison share the assumption that people do not evaluate situations in absolute terms, but rather in relative terms, using different kinds of benchmarks. One of the most influential theoretical models based on relative deprivation was put forward by Crosby (1976). According to Crosby's model, as well as to all relative deprivation theories, a crucial role in the evaluation of fairness is played by the comparison between one's own situation and that of someone else chosen, for reasons to be investigated (we will return to this major point later), as a relevant referent (for more detail on the issue of comparison referents in justice research see Berger et al. 1972; Berger et al. 1985).

The concept of relative deprivation has been applied to many fields of research, including the division of household labor. To shed light on the mechanisms of fairness evaluation in this domain, Major (1987, 1993) and Thompson (1991) developed an influential theoretical framework. Among other factors, these scholars discuss the role of comparison referents, i.e., benchmarks chosen by individuals to evaluate the fairness of their own (or their partner's) share of household labor. Comparison referents define what people deserve and are entitled to receive in the performance of domestic activities.

Other scholars who have devoted attention to the role of comparisons in social reality (known as social comparison theorists, see the pioneering work by Festinger 1954 and, for an update and a critical discussion, Wood 1989) emphasize that in the absence of well-established behavioral standards, the desire and the need for comparisons is even higher, as they orient individual choices and affirm a new, widely-accepted social reality. This is the case of housework division, since in most European countries dual-earner couples have become the norm (European Commission 2014: 47, Tab. 4), but most adults grew up in traditional families, where the father was the sole (or the main) breadwinner and the mother had primary responsibility for housework and care. Housework division is thus an uncertain and sometimes conflictual issue for people in contemporary families. They, unlike their parents, particularly seek information on others' behaviors in this domain (Himsel \& Goldberg 2003). In addition, research (Grunow et al. 2012; Lam et al. 2012) has shown that housework division is not a static arrangement which is unalterable along the couple's life-course. Thus, comparison referents are also an important source of information when adjustments occur in the division of paid and unpaid work between partners.

Different comparison referents can be considered in evaluating fairness. Comparisons may be made with the spouse (hereinafter the terms spouse, husband, wife and marital relationship are also used for unmarried cohabiting couples). In this case, the term relational comparisons is used (Buunk \& VanYperen 1991). Other referents may be similar others of the same sex in a reference group, i.e., relatives, friends, colleagues and acquaintances, in which case they are designated as referential comparisons (Buunk \& VanYperen 1991). In addition, a significant role is also played by normative comparisons derived from beliefs regarding the 'average' behavior of men and women in a certain domain (Major 1993). Lastly, references to past family models, i.e., mother's or father's domestic behaviors, have also been considered in analyzing housework fairness (Gager 1998; Himsel \& Goldberg 2003; Carriero 2011).

According to Major (1987), referential or within-sex comparisons are more likely to have a positive (i.e., enhancing) impact on fairness evaluation than between-sex ones: given the strong gender inequality in the division of domestic work found even in gender egalitarian societies, between-sex comparisons easily provoke feelings of injustice (for women) or guilt (for men). One could argue that Major's theoretical framework refers to the mid of the eighties, when gender differences in domestic contribution where larger than nowadays. So, at the present between-sex comparisons should be less dangerous, since they are less likely to lower fairness perception than in the past. However, women continue to do a disproportionate share of household labor even in recent times and in the most egalitarian countries like Sweden and Denmark. According to a study carried out in Sweden (Evertsson 2014), men spend on average 9 hours in housework each week, compared with women's 15 hours. Another study (Craig \& Mullan 2011) shows that in Denmark mother spend twice as much time on childcare than fathers: about two hours per day vs. about one hour. Given this evidence, it is reasonable to suppose that between-sex comparisons continue to be a source of feelings of injustice or guilt also nowadays. 
husband and does not feel entitled to more (Hochschild 1989)[1]. When evaluating their husbands' domestic behavior, moreover, women usually consider what the partners of their female friends do. Men, in turn, compare the help they give in the home with that of male friends or with even more favorable benchmarks such as their fathers or grandfathers (LaRossa 1988; for empirical evidence see also Gager 1998).

This use of comparison referents can be considered a dissonance reduction strategy, i.e. an action aiming to reestablish consonance between attitudes, beliefs and behaviors (Festinger 1957, 1999; Harmon-Jones et al. 2009). Among the different means that, according to Festinger, reduce dissonance, namely changing behaviors, changing cognitions and adding new cognitions, the use of comparison referents is an example of the last one: a woman whose partner does a limited amount of housework may convince herself that her domestic arrangement is not so bad through the comparison with another woman whose partner does nothing at all. As shown by a large body of empirical research, people often use the different reduction strategies to rationalize inconsistent attitudes and behaviors in different domains of their lives: for instance, in smoking (Kneer et al. 2012), recycling (Kimura \& Shinoki 2007) or suffering from domestic violence (Enander 2011).

If comparison referents are a means to reduce cognitive dissonance, their choice is, as Homans wrote (cited in Kellerhals et al. 1988, p. 44), teleological, i.e., serving to make sense of a certain judgment or achieve a goal. In other words, the behavior of the comparison referent affects how the fairness of housework division is evaluated, but the choice of the comparison referent is in turn affected by this division or by the judgment of it, as it is made in order to find a benchmark that helps in avoiding feelings of unfairness and cognitive dissonance or in corroborating one's own feelings of injustice.

In our view, the problem of self-serving bias (i.e., peoples' tendency to credit themselves with more positive attributes than other people; see e.g., Roese and Olson 2007) in the selection of comparison referents does not affect all the possible types of comparison in the same way. This issue mainly affects referential comparisons, since a favorable same-sex referent can be found within the peer group. Normative comparisons also appear to be at risk, since individuals may estimate (or believe in) different behaviors of "average" men or women that are not in open contrast with their own. According to Gager (1998), men see the average man as a sort of do-nothing dad (although this statement should be considered context-sensitive). By contrast, the bias should not be present in the case of specific referents such as parents' or partner's behaviors. Here again, however, individuals may over/underestimate the referent's real contribution in order to put their own situation in a better light. In the case of parents, the long recall period may facilitate biased estimations.

2.10 The risk of self-serving bias in the choice of comparison referents has been stressed by many scholars (see, e.g., Taylor, Wayment, \& Carrillo 1996 and the conclusions of Major 1987). According to Wood (1989), comparison referents are often used to maintain and reinforce a positive view of one's arrangement, rather than for rational and unbiased self-evaluation. Himsel and Goldberg (2003; see also Gager 1998 for a similar argument) unequivocally stated that in evaluating housework fairness, contemporary partners 'pick and choose social referents that help affirm the normalcy and accuracy of their own situation' (p. 860). However, the empirical research carried out so far on housework fairness and comparison referents (see below) has substantially ignored this problem, with the serious risk of producing biased results.

2.11 Considering the theoretical importance of comparisons in the evaluation of justice, and the extensive literature addressing the issues related to housework, it is somewhat surprising that the studies carried out so far on the effect of comparison referents on perceptions of housework fairness are so very few in number (Freudenthaler \& Mikula 1998 for Austria; Gager 1998 in a qualitative American study; Kluwer et al. 2002 for the Netherlands; Himsel \& Goldberg 2003 for US; Mikula et al. 2009 in a study devoted to Austria, Germany and Switzerland; Carriero 2011 for Italy) [2]. Other studies (Buunk et al. 2000; Grote et al. 2002) only tested the effect of the frequency of comparison on the evaluation of fairness, neglecting that of the outcome. All this research refers to micro-level interactions, as can be expected considering the topic tackled here. Greenstein (2009) showed a link between comparison referents and the institutional and cultural context, even if his study was not explicitly devoted to social comparisons and housework fairness. The type of normative referent he considers is nation-level gender equity, rather than people's perception of 'average' male and female domestic behavior.

2.12 On the whole, some evidence in line with theoretical predictions has been found, even if the studies cited above were carried out in different institutional and cultural contexts. However, not all the different types of referent had the expected effect. For instance, according to Himsel and Goldberg (2003), women's satisfaction with housework division increased both when they did less at home than their own female friends and when their husbands did more than other male referents. For men, however, only the comparison between their wives' and mothers' domestic work affected the fairness evaluation. In some cases, the studies reported conflicting findings: for instance, neither Mikula et al. (2009) nor Carriero (2011), nor Kluwer et al. (2002) found the female-peer effect on women's sense of fairness reported by Himsel and Goldberg (2003); conversely, these studies show a malepeer effect on men's evaluation that was not found by Himsel and Goldberg. The problem of self-serving bias in the choice of comparison referents could contribute to explaining these inconsistencies. Another explanation stems from the fact that almost all these studies (Carriero 2011 is the only exception) are based on small convenience samples which make generalization impossible. Their sample sizes vary from the 25 couples sample of Gager's qualitative analysis (1998), to a maximum of 293 couples sample used by Kluwer and colleagues (Kluwer et al., 2002). In the study carried out by Mikula and colleagues (2009) in Austria, Germany and Switzerland, the sample size is about 200 couples for each country[3]. Further research is thus required to 


\section{Motivation of the Study and Hypothesis}

3.1 This study aims to add new evidence on the effect of comparison referents on housework fairness, an underexplored topic. Our attention is focused on Italian dual-earner couples with at least one child under 13 years old. The particular circumstances of this target group, characterized by multiple sources of time pressure (from work and family responsibilities), made the choice of this sample highly relevant because the issue of perceived fairness of the division of housework is particularly salient in such households. Indeed, almost all studies carried out so far on social comparisons and housework fairness are based on dual-earner couples. Generally speaking, the most interesting research questions about housework division mainly regard such couples, in which the inconsistency between the labor market transformations of recent decades and domestic behaviors are well represented. Male breadwinner and female breadwinner couples are either less interesting or too rare.

Our work improves on the existing knowledge in four main respects. First, the empirical test presented here is based on a probability sample which makes it possible to generalize its findings to a wider population, unlike the small convenience samples used in the research carried out so far. Second, our study sheds light on the effect of a wide range of comparison referents that have never been considered in the same investigation; some have never been tested before. Third, we provide evidence on the self-serving bias present in the choice of some referents. Fourth, we introduce a methodological innovation with the adoption of the vignette technique in a survey-based experimental design, which in our opinion is an effective strategy (see next section) for addressing the problem of self-serving bias in the choice of comparison referents. Vignettes in experimental designs have seldom been used in family research (see, e.g., Kluwer 1998; Gaunt 2013), and never in the study of the topic tackled here.

The following sections of the article will test a single hypothesis. However, this hypothesis should be interpreted differently according to the comparison's object and respondent's sex:

Favorable comparison referents enhance the sense of fairness about housework division, while unfavorable ones decrease it.

For a man, favorable means that his own housework time is greater than the male comparison referent's time or that his wife's housework time is lower than the female comparison referent's time; on the contrary, unfavorable means that his own housework time is lower than the male comparison referent's time or that his wife's housework time is greater than the female comparison referent's time.

For a woman, favorable means that her own housework time is lower than the female comparison referent's time or that her husband's housework time is greater than the male comparison referent's time; on the contrary, unfavorable means that her own housework time is greater than the female comparison referent's time or that her husband's housework time is lower than the male comparison referent's time.

\section{Research Design and Sample}

4.1 Our study is based on two different research designs: a survey analysis of a sample of dual-earner couples and an experimental-vignette technique embedded in an online questionnaire administered to the same respondents. The first design allowed us to test the effects of a wide range of comparison referents on respondents' evaluation of the fairness of their own division of housework, but left us with the problem of selfserving bias associated with survey data. The second design enabled us to avoid this problem by leveraging the randomization of independent variables typical of the experimental-vignette technique, without relinquishing the generalizability of the survey method.

Vignettes are verbal descriptions of fictitious (but realistic) situations to be evaluated by subjects, often, but not necessarily, within an experimental research design (Finch 1987; Ganong \& Coleman 2006; Wallander 2009; Mutz 2011, ch. 4). In this kind of design, vignettes contain one or more variable elements calledfactors (i.e., variables deemed to affect an individual's judgment about the vignette) that are randomly assigned to respondents. Random assignment makes it possible to assess the causal effect of the factors on people's judgments. In our case, the domestic behavior of the comparison referent represented in the vignette is randomly assigned. In this way, respondents cannot pick and choose the kind of referent (see below). A strength of this technique is that, unlike laboratory experiments, vignettes can be implemented in a representative survey in order to generalize the findings to a wider population.

Our sample was randomly drawn from the landline telephone directories of four provinces of Piemonte, a region in northwestern Italy. By means of a few screening questions, we selected dual-earner married or cohabitating couples with at least one child under 13 years old. Although our sample is confined to four northern provinces, it can be considered fairly representative of Italian households in similar family conditions living in most parts of the country. The female employment rate in Piemonte, though higher than the national average, is not very different from the north and central areas of the country (Eurostat 2015; see Labor Force Survey regional series). Moreover, as we have calculated from the latest Italian time use data (2008-09), the division of housework among dual-earner couples in Piemonte, as measured by the ratio of women's to men's time devoted to domestic chores, is almost identical (2.7) to that of other north-central regions (2.8 on average) and only lower 
(i.e., less traditional) than that of southern regions (3.9). We will discuss implications of the lack of representativeness of the southern area in our sample in the concluding section.

For greater clarity, the survey and the vignette analyses are presented separately below. For each design, information about data and method are provided, followed by the presentation of the findings.

\section{Survey Analysis}

\section{Data and Method}

For the survey data, we interviewed 828 married and unmarried couples by phone (both partners were interviewed, yielding 1656 individuals, response rate $42 \%$ ) using a structured questionnaire about the division of domestic and care tasks, perceived fairness, gender roles, and paid work. Data were collected from October 2010 to February 2011 (descriptive statistics of the sample are given in the Appendix).

The dependent variable of the survey analysis is respondent's perceived housework fairness. It was probed with the following question: 'Regarding the division of housework with your partner, do you personally think that what you do is... (1 - Much more than fair, 2 - A bit more than fair, 3 - Fair, 4 - A little less than fair or 5 - Much less than fair)?'. Given its empirical distribution, we recoded this variable as $1=$ fair, $0=$ unfair, where 'unfair' means less than fair for men or more than fair for women, and includes the very few cases who think they do more than fair, among men, or less than fair, among women. We then analyzed this variable separately for women and men through logistic regression[4].

The main independent variables are a series of questions asking wives and husbands to compare their own and their spouse's housework time with that of four "concrete" and two "abstract" comparison referents: father and mother (past family models), male and female friends (referential comparisons), the 'average' Italian man and woman (normative comparisons). We do not consider here comparisons with the partner (relational comparisons), because their effects on fairness evaluation are implicitly analyzed by the large number of studies (see, e.g., Braun et al. 2008; Ruppanner 2008; Young et al. 2015) focusing on the effect of relative share of housework on housework fairness. Moreover, as stated by Major (1987) between-sex comparisons are much rarer than within-sex ones. Respondents had to say if their own (or their spouse's) housework time was about equal, lower or higher than the proposed comparison referent. Note that, as regards normative comparisons, we are able to contrast respondents' perceptions of the time spent on housework by an average man or woman with objective time use data (estimated means from the 2008-09 Italian survey). In this way, the possible presence of a self-serving bias can be established. As regards referential comparisons, we asked respondents to think about the friend they visited most and to make comparisons with him/her. In this way, we tried to attenuate the possibility that respondents chose their comparison referents for convenience reasons. In all instances, husbands had to compare themselves to other men (father, male friend, the average Italian man) and their wives to other women (their mother, their friend's wife, the average Italian woman). Similar within-sex comparisons applied to wives.

To summarize, for both husbands and wives, we tested the effect of six main independent variables (three respondent vs. referent and three respondent's spouse vs. referent comparison outcomes) on perceived fairness (the distribution of these variables is given in the Appendix). It should be borne in mind that the six comparison referents are not mutually exclusive, so we assessed their relative importance by contrasting their effects on perceived fairness.

Our regressions included several antecedent and concomitant variables that may affect perceived fairness as well as the outcome of specific comparisons. In addition to standard demographic variables (age, education, and partner's education), we selected variables representing the division of responsibilities within the couple: respondent's and spouse's working hours, respondent's percentage of housework, respondent's percentage of childcare, and hours of paid household help received[5]. In addition, we controlled for respondent's gender ideology, given that several studies have indicated that it may influence perceived fairness (Greenstein 1996; Lavee \& Katz 2002; Braun et al. 2008). We measured gender ideology using a scale of traditionalism ( $a=$ $0.62)$ obtained by summing seven Likert-type items. The items are: 'A woman needs children in order to feel fulfilled', 'It is not good for the couple if the woman earns more than the man', 'In case of marital disruption it is better for children to live with the mother rather than with the father', 'A pre-school child is likely to suffer if his/her mother has a full-time job', 'When parents need care, it is more natural for daughters to perform this task than sons', 'A man needs children in order to feel fulfilled', 'A woman should be willing to devote less time to paid work for the sake of the family'. In the models testing the effect of past family models, we also controlled for parent's education and geographical origin (whether born in the South of Italy, where the division of labor is more traditional, or not).

In order to maximize comparability across the six regressions, our analyses were performed on the subsample obtained by list-wise deletion of missing values[6].

\section{Results}

As in previous research, most women (62.8\%) and men (57.4\%) reported that their share of housework is fair, although the former do on average two thirds of the chores and the latter about one third (results not 
shown). A substantial minority of men (40.3\%) admitted their share of housework is (a little or much) less than fair, while a tiny proportion (2.3\%) reported it is more than fair. Among women, $33.6 \%$ of them said they do (a little bit or much) more than fair, while $3.6 \%$ believed they do less than fair.

Regression analyses of survey data show the effects of the different comparison outcomes on respondents' perception of fairness of their own domestic arrangement. Since logistic regression coefficients are not easily interpretable, Table 1 shows average predicted probabilities of evaluating the housework division as fair as a function of the three possible outcomes (the respondent or his/her partner devotes more time to housework, about the same time, less time) of each comparison, separately for men and women[7]. The full set of regression coefficients is given in the Appendix.

Table 1. Fairness perception by various comparison outcomes. Average predicted probabilities from logistic regressions of survey data; separate analyses by sex.

\begin{tabular}{|c|c|c|c|c|c|c|}
\hline \multirow[b]{3}{*}{$\begin{array}{l}\text { Comparison } \\
\text { outcomes }\end{array}$} & \multicolumn{6}{|c|}{ Men's predicted probability of evaluating the housework division as fair } \\
\hline & \multirow[b]{2}{*}{$\begin{array}{l}\text { Respondent } \\
\text { vs. his } \\
\text { father }\end{array}$} & \multirow[b]{2}{*}{$\begin{array}{l}\text { Respondent's } \\
\text { partner vs. } \\
\text { his mother }\end{array}$} & \multicolumn{2}{|c|}{ Type of comparison } & \multirow[b]{2}{*}{$\begin{array}{l}\text { Respondent } \\
\text { vs. average } \\
\text { Italian man }\end{array}$} & \multirow[b]{2}{*}{$\begin{array}{l}\text { Respondent's } \\
\text { partner vs. } \\
\text { average Italian } \\
\text { woman }\end{array}$} \\
\hline & & & $\begin{array}{l}\text { Respondent } \\
\text { vs. his male } \\
\text { friend }\end{array}$ & $\begin{array}{l}\text { Respondent's } \\
\text { partner vs. his } \\
\text { friend's wife }\end{array}$ & & \\
\hline More time & $0.574 \mathrm{~ns}$ & $0.499 \mathrm{~ns}$ & $0.626+$ & $0.535 \mathrm{~ns}$ & $0.651^{* *}$ & $0.549 \mathrm{~ns}$ \\
\hline $\begin{array}{l}\text { About the same } \\
\text { time (ref. cat.) }\end{array}$ & 0.633 & 0.581 & 0.558 & 0.589 & 0.529 & 0.588 \\
\hline Less time & $0.455 *$ & $0.585 \mathrm{~ns}$ & $0.403 *$ & $0.599 \mathrm{~ns}$ & $0.400 *$ & $0.562 \mathrm{~ns}$ \\
\hline \multirow[t]{2}{*}{$\mathrm{N}$} & 684 & 684 & 684 & 684 & 684 & 684 \\
\hline & \multicolumn{6}{|c|}{ Women's predicted probability of evaluating the housework division as fair } \\
\hline & \multicolumn{6}{|c|}{ Type of comparison } \\
\hline $\begin{array}{l}\text { Comparison } \\
\text { outcomes }\end{array}$ & $\begin{array}{l}\text { Respondent } \\
\text { vs. her } \\
\text { mother }\end{array}$ & $\begin{array}{c}\text { Respondent's } \\
\text { partner vs. } \\
\text { her father }\end{array}$ & $\begin{array}{l}\text { Respondent } \\
\text { vs. her female } \\
\text { friend }\end{array}$ & $\begin{array}{l}\text { Respondent's } \\
\text { partner vs. her } \\
\text { friend's } \\
\text { husband }\end{array}$ & $\begin{array}{l}\text { Respondent } \\
\text { vs. average } \\
\text { Italian } \\
\text { woman }\end{array}$ & $\begin{array}{l}\text { Respondent's } \\
\text { partner vs. } \\
\text { average Italian } \\
\text { man }\end{array}$ \\
\hline More time & $0.612 \mathrm{~ns}$ & $0.627 \mathrm{~ns}$ & $0.572 \mathrm{~ns}$ & $0.639 \mathrm{~ns}$ & $0.626 \mathrm{~ns}$ & $0.667^{* *}$ \\
\hline $\begin{array}{l}\text { About the same } \\
\text { time (ref. cat.) }\end{array}$ & 0.658 & 0.632 & 0.639 & 0.632 & 0.618 & 0.548 \\
\hline Less time & $0.590 \mathrm{~ns}$ & $0.452 *$ & $0.585 \mathrm{~ns}$ & $0.485 * 8$ & $0.575 \mathrm{~ns}$ & $0.542 \mathrm{~ns}$ \\
\hline $\mathrm{N}$ & 695 & 695 & 695 & 695 & 695 & 695 \\
\hline
\end{tabular}

Asterisks indicate differences with respect to the reference category (about the same): ${ }^{*} p<0.01{ }^{*} p<0.05+p<0.1$ ns: difference not statistically significant

Control variables: age, education, partner's education, working hours, partner's working hours, \% of housework, $\%$ of childcare, hours of paid household help received, gender ideology and, only for comparisons with parents, parental education and geographical origin. See the Appendix for the full set of coefficients.

Comparison outcomes are respondents' answers to questions about their (or their partner's) time spent in housework compared to various referents

The main message conveyed by the data is that comparison referents work in line with theoretical predictions when the object of evaluation is the male domestic contribution. No significant effect is found either when women compare themselves with their female counterparts (mothers, friends, the average Italian woman), or when men do the same with their partner's domestic contribution. This can be indicative of the fact that neither men nor women make use of female comparison referents for their housework fairness evaluations. Conversely, the expected significant effect of both favorable and unfavorable comparisons on fairness perception is generally found when male respondents compare themselves with other same-sex referents and when female respondents do the same with their partner's behavior.

5.10 Entering into detail, the effects of the comparisons for husbands' judgments are significant and quite strong when their outcomes are unfavorable (i.e., the respondent does less housework than the referent): the predicted probability of perceiving fairness decreases by about 0.15 on average to arrive at values well below 0.50 . For instance, when a husband thinks he does the same amount of housework of his male friend, the probability of evaluating the housework division as fair is 0.56 . If he thinks does less, the probability decreases to 0.40 . When the outcome is favorable (i.e., the respondent does more housework than the referent), the analyses confirm the expected significant increase in perceived fairness, even if not in the case of comparisons with the father (the difference is not significant). For instance, when a husband thinks he does the same amount of housework of the average Italian man, the probability of evaluating the housework division as fair is 0.53 . If he thinks he does more, the probability increases to 0.65 . Based on the strength of the effects (differences in predicted probabilities), it can be said that the comparison with their friends and average Italian are the most influent on men's judgments.

5.11 As regards wives' judgments, the effect of comparisons significantly decreases the sense of fairness when the outcome is unfavorable (i.e., the respondent's husband does less housework than the referent), with 
the exception of the comparison with the average Italian man. If in wife's opinion her father did the same amount of housework than her husband, the probability of evaluating the housework division as fair is 0.63 ; if her husband does less, the probability decreases to 0.45 . The same probabilities of the comparison with her friend's husband are 0.63 and 0.49 , respectively. When the outcome is favorable (i.e., the respondent's husband does more housework than the referent), the sense of fairness is not significantly affected, except for the comparison with the average Italian man, in which case the probability of perceiving fairness is significantly higher (from 0.55 to 0.67 ). Based on the strength of the effects, for women the comparison between her husband and her father is more influential on their perceived fairness than the other comparisons. By contrast, the latter seems to be less decisive in switching wives' judgments from fair to unfair (the predicted probabilities remain around the 0.5 threshold or above), unlike the case of men.

5.12 Although these results do show an effect of men's behavior as comparison referent, we may suspect that self-serving bias has a distorting effect on the choice of referents. Indeed, we found evidence that male respondents underestimate the housework time of the 'average' Italian man. This raises the suspicion that they need to cast their own domestic contribution in a better light. Most husbands (83.1\%) reported they devote more or about the same time to housework as their same-sex Italians do. However, their reported weekly housework time (8.9 hours on average among those who say 'I do more' and 7.5 hours among those who say 'I do about the same') is well below the estimated means we calculated from the Italian time use survey 2008-09 (10.3 hours) ${ }^{[8]}$. As regards the comparison with friends, we do not have objective data for comparison, but some clues of a possible self-serving bias can be detected here as well. We found that the majority of husbands and wives systematically rate men's behavior as better than that of friends: $50 \%$ of men think they do more at home than their male friends, while just $14 \%$ think they do less. For women, $49 \%$ of them think their husband does more housework, while only $20 \%$ admit he does less (results not shown). The use of an experimental-vignette design can help us to overcome the problem of the self-serving bias.

\section{Vignette Analysis}

\section{Data and Method}

During Spring 2013, all individuals included in the survey sample were contacted again to collect their email address. We were able to reach 1365 individuals (82\%) from the initial sample (1656 individuals), to whom the online questionnaire with the vignettes was sent. The online questionnaire contained eight vignettes dealing with family issues. For the vignette analyzed here, we received answers from 691 individuals ( $51 \%$ of the email list, or $42 \%$ of the initial sample). As can be expected, the considerable drop in the number of cases did not occur entirely at random. Indeed, actual respondents were positively selected by education, as is often the case with all survey modes. For other important characteristics such as gender, division of housework, and gender attitudes, the differences between the survey and the vignette sample were negligible (descriptive statistics of the sample are given in the Appendix).

The vignette presented here investigates the effect of the referential comparison (male friends) on husbands' domestic behavior. We focused on husband's behavior because we knew from our survey data that only male behavior, through the comparison with other men, has an impact on perceived fairness. The choice of friends as referent was suggested by our findings about the relevance of this kind of comparison, and by Gager's (1998) study, which clearly shows that peers are the most important comparison group.

Since self-serving bias leads men to avoid guilt feelings by not comparing themselves with other men who do more at home, this was one of the possible scenarios we asked respondents to evaluate. However, it was difficult to imagine a credible situation and a realistic stimulus that could be used to detect an effect of the comparison referent on judgments. Accordingly, what we devised is a test of the effect of an exogenous comparison opportunity on the likelihood of a certain behavioral change on the part of the vignette character. This, of course, is not a direct judgment of fairness, but we assumed that such a behavioral change will, in the long run, be followed by a corresponding change in perceived fairness in order to avoid cognitive dissonance. Moreover, it is easier to change one's judgment of fairness than to make an actual change in domestic behavior, which would mean subtracting time from other daily activities and, in some cases, developing new domestic skills. So, this can be considered a conservative test of comparison referents: if they affect the domestic behavior, they affect even more the fairness evaluation.

Here is the translation of the vignette's text (varying factors in italics in brackets):

\footnotetext{
Beatrice and Riccardo, 34 and 35 years old, respectively, form a family and (do not have children / have a child / have two children). Both spouses (finished compulsory education / have a high-school diploma / have a university degree) . Beatrice spends (a couple of hours a day less than / the same number of hours a day of / a couple of hours a day more than) Riccardo at her job and contributes to family income with approximately $(700 / 800 / 900 / \ldots 1800)$ euros per month. Beatrice takes care of almost all the housework and this situation creates some tension with Riccardo. Riccardo talks about this matter with his male friends and finds that (most of them do almost nothing around the house / most of them take charge of about half of the housework). Imagine 100 families like those described above. How many people in Riccardo's shoes would decide to get more involved in housework?
} 
the five vignette factors, the main independent variable is friends' behavior: it enables us to overcome the problem of self-serving bias in the choice of referents, because the comparison outcome is experimentally manipulated. The vignette's other factors are included in the model as control conditions that could alter respondents' answers and, at the same time, provide interviewees with additional details about the scenario in order to make it more realistic.

Unlike survey data on perceived fairness, here the randomization of factors makes controlling for respondents' characteristics theoretically and practically useless [9]. For this reason, no respondents' characteristic is included in the main regression model. Nonetheless, respondent's characteristics (i.e., sex, education, gender ideology, own housework division, union duration) are tested in interaction with the vignette's factors, with the aim of assessing whether the factors' effects vary across subgroups [10].

Unlike the so-called factorial surveys (Wallander 2009), where subjects are given multiple versions of the same vignette, respondents in our study evaluated only one version of a vignette. Our vignette design can thus be classified as a between-subjects design whose main advantage, given the large number of cases, is that the effects of various factors can be tested without the sensitization and carryover effects resulting from multiple evaluations of the same vignette (Greenwald 1976). The high number of possible combinations of each factor and levels is not a problem here because we are interested in the main effect of one factor (comparison referents' behavior) and not in the effects of all its possible combinations with the other factors.

\section{Results}

According to our analysis (Table 2), the probability that Riccardo will do more at home increases, as expected, if his friends share housework equally rather than if they do almost nothing (+6.9 percentage points). None of the other vignette factors included in the regression model had significant main or interactive effects on judgments. Although there are no differences in the effect of the comparison between male and female respondents (i.e., the interaction with respondent's sex is not significant), we found that men's and women's answers do differ on average by 9 percentage points, the former being more inclined than the latter to believe that Riccardo will change his behavior (result not shown).

Table 2. OLS regression results from vignette data. Effects of factors on respondents' subjective probabilities of a greater involvement in housework by the vignette character

\begin{tabular}{lccc}
\hline & Coef. & Std. Err. & P-value \\
\hline Comparison outcome (ref: friends do nothing) & & & \\
Friends share equally & 6.88 & 1.62 & 0.000 \\
Wife's paid work hours (ref: the same) & & & \\
Two hrs less than husband & -2.53 & 1.99 & 0.203 \\
Two hrs more than husband & -3.08 & 2.00 & 0.125 \\
Children at home (ref: two) & & & \\
One child & -1.74 & 2.00 & 0.385 \\
No child & 1.26 & 1.97 & 0.525 \\
Spouses' education (ref: both < secondary) & & & \\
Both secondary school & -1.15 & 2.02 & 0.569 \\
Both university & -0.81 & 1.98 & 0.683 \\
Income (continuous) & 0.00 & 0.00 & 0.306 \\
Constant & 35.98 & 3.79 & 0.000 \\
Adj. R2 & & & \\
$\mathrm{N}$ & 0.023 & & \\
\hline
\end{tabular}


referents share equally, the probability of a change in Riccardo's domestic contribution raises by 12.7 percentage points. No other interaction effect was found to be significant.

\section{Discussion and Conclusions}

7.1 In this study we used both survey data (gathered, by contrast with previous studies, from a probability sample) and experimental vignette data to shed further light on the effect of comparison referents on housework fairness. Here we summarize our main findings and discuss their implications, as well as some issues related to the role of the context and limitations of our work.

The findings from survey data show that referential and normative comparisons, as well as past family models, do in fact play a significant role in housework fairness evaluation. To overcome the self-serving bias that could affect survey results, we devised an experimental vignette design, where the choice of referents is randomly assigned. With this design we were able to confirm that unfavorable male comparison referents affected individuals' judgments in the expected direction. According to our findings, referents are not simply used to justify an established behavior, as might be suspected when relying on survey data only, but to orient decision-making.

Our survey data analysis provided another clear-cut and significant result: only comparisons involving men's behavior have an influence on fairness evaluation, for both men and women. It must be stressed that this result cannot be affected by self-serving bias. Since this bias (when present) increases the effect of comparison referents on housework fairness (they are chosen precisely for this purpose), the lack of effect of female comparisons found here can be considered reliable. A possible explanation is that in a gender-unequal country like Italy, women's greater engagement in household tasks is taken for granted, hence comparisons involving them do not enter into the fairness evaluation process. In the recent past, the same could apply to male behavior, given that men's lack of domestic collaboration was the rule. Nowadays, after women's entry in the workforce, men are increasingly expected to provide at least some help; consequently, even a small contribution (or the lack of it), if compared to someone else's, can become relevant in establishing housework fairness.

Survey data also showed that favorable comparison referents have weaker or even not significant effects than favorable ones. As regards women's judgments, this is consistent with other research on social justice matters and perceived equity, indicating that being under-rewarded is more likely to be felt as injustice than being over-rewarded (Shepelak \& Alwin 1986; Jasso 1990, 1999). As regards men's judgments, however, their situation vis-à-vis unfavorable referents is probably best understood in terms of relative advantage (Leach et al. 2002). The difference in the effect of unfavorable and favorable referents can be explained by hypothesizing that guilt feelings (in the case of unfavorable comparisons) override resentment feelings (in the case of favorable comparisons).

It can be supposed that the effect of comparison referents on housework fairness is attributable to those people who, being more uncertain about their family and gender roles, need information in order to evaluate their domestic contribution: social comparison theorists claim that they are exactly the kind of people who look at others' behavior to reduce uncertainty. This does not hold true for people with clear ideas on this issue: since they are only looking for confirmation of the validity of their opinions and behaviors, they only need to pick and choose the 'right' referents. This supposition finds support in our vignette, at least for men: the main effect of comparison referents holds on average, but is strongly driven by men whose gender ideology lies in between egalitarian and traditional positions, and who probably need external information to evaluate housework fairness. On the contrary, for both egalitarian and traditionally minded men, comparison referents exert no effect. This result, however, is not confirmed by a similar analysis in our survey data. Consequently, this issue remains open for further research.

It must also be stressed that the effects of the comparison referents found in our analyses may be underestimated. This is due to the fact that this study is based on couples with children who have been living together from many years (13 on average). As these couples probably have already established their housework division, comparison referents would play a role only in the event of changes in their domestic arrangement. In the case of people at the beginning of their cohabitation, who are negotiating the division of responsibilities, comparison referents could be more relevant, and their effect on fairness evaluation stronger. According to this reasoning, comparison referents should have a greater effect on housework fairness evaluation for certain specific subgroups of the population in particular and for a limited time period. We tried to test this further hypothesis by analyzing the interaction effects between comparison outcomes and marital duration in our data, and found no differences (results not shown). However, this does not allow us to reject this argument categorically. Further research could focus on couples at the beginning of cohabitation, possibly by looking for differences in the effects of comparison referents between them and other, long-standing couples.

As regards the context of this study, it must be noted that our sample is fairly representative of Italian households in similar family conditions, but not of the southern areas. At the beginning of this article we stressed that, given the strong traditional orientation of the Italian institutional and cultural context and the low number of dual-earner couples, people living in this family arrangement could be particularly responsive to the domestic behavior of others in defining the "right" way to divide housework. We might expect that in conservative southern areas, where dual-earner couples are even rarer, the effect of comparison referents should be stronger than in the rest of Italy. Thus, the effect of comparison referents found in our analysis could be slightly underestimated 
A limitation of our study should be acknowledged. It regards the correspondence between personal fairness judgments and judgments made in response to a vignette. The strength of the vignette method lies in the manipulation of theoretically relevant factors affecting the individual's judgment in order to assess their causal effects. However, since vignettes usually depict hypothetical situations, there is no a priori reason to believe that the same factors will act in the same way in real life situations. In other words, the vignette method has a problem of external validity. There is evidence that vignettes are related to real-life behavior (see, e.g., Horne 2003; Ganong \& Coleman 2005, 2006), but there can be no doubt that the nexus between vignette judgments and respondents' actual judgments of their housework divisions has still not been fully specified. This kind of problem has already been acknowledged by Bernstein and Crosby (1980) and by Kluwer (1998), who nevertheless maintain that the advantages of the vignette method outweigh its disadvantages (see also Duncan 2008 for good reasons to prefer causally robust methods despite their external validity problems). In line with this reasoning, we think that vignettes are worth further application in the housework domain, as well as in other fields of research.

\section{Appendix 1}

Descriptive statistics for survey and vignette samples

\begin{tabular}{lcccccccc}
\hline & \multicolumn{3}{c}{$\begin{array}{c}\text { Survey sample } \\
\text { Men }\end{array}$} & \multicolumn{4}{c}{$\begin{array}{c}\text { Vignette sample } \\
\text { Women }\end{array}$} & \multicolumn{2}{c}{$\begin{array}{c}\text { Men } \\
(\mathrm{N}=828)\end{array}$} & $\begin{array}{c}\text { Women } \\
(\mathrm{N}=828)\end{array}$ & $\begin{array}{c}\text { W=322) } \\
(\mathrm{N}=369)\end{array}$ \\
\hline Variable & $\mathrm{M}$ & $\mathrm{SD}$ & $\mathrm{M}$ & $\mathrm{SD}$ & $\mathrm{M}$ & $\mathrm{SD}$ & $\mathrm{M}$ & $\mathrm{SD}$ \\
\hline Age & 43.1 & 5.6 & 40.5 & 5.1 & 43.1 & 5.7 & 40.8 & 4.8 \\
Years of education & 12.8 & 3.3 & 13.8 & 3.1 & 13.2 & 3.2 & 14.5 & 3.0 \\
Weekly work hours & 45.5 & 10.3 & 33.0 & 10.1 & 45.0 & 9.8 & 32.5 & 9.9 \\
Traditional gender attitudes scale (1-5) & 2.6 & 0.8 & 2.6 & 0.8 & 2.5 & 0.8 & 2.5 & 0.8 \\
\% of housework & 34.3 & 14.6 & 69.7 & 15.9 & 34.9 & 15.0 & 68.6 & 16.6 \\
\% of childcare & 40.2 & 13.1 & 62.3 & 14.4 & 40.8 & 12.7 & 61.9 & 14.6 \\
Hours of paid household help received & 6.1 & 13.7 & 6.1 & 13.7 & 7.1 & 14.2 & 7.3 & 15.4 \\
Own fairness perception (\% fair) & 57.4 & & 62.8 & & 56.5 & & 61.8 & \\
\hline
\end{tabular}

Distribution of comparison outcomes (\%), by sex

\begin{tabular}{|c|c|c|c|c|c|c|}
\hline Men & & & Comparis & on referent & & \\
\hline Comparison outcomes & Father & Mother & $\begin{array}{l}\text { Male } \\
\text { friend }\end{array}$ & $\begin{array}{l}\text { Female } \\
\text { friend }\end{array}$ & $\begin{array}{l}\text { Average } \\
\text { Italian } \\
\text { man }\end{array}$ & $\begin{array}{l}\text { Average } \\
\text { Italian } \\
\text { woman }\end{array}$ \\
\hline More time & 82.2 & 15.3 & 51.6 & 35.5 & 48.7 & 31.4 \\
\hline About the same time (ref. cat.) & 11.0 & 31.4 & 34.3 & 47.3 & 38.4 & 53.8 \\
\hline Less time & 6.8 & 53.3 & 14.1 & 17.2 & 12.9 & 14.9 \\
\hline$N$ & 684 & 684 & 684 & 684 & 684 & 684 \\
\hline Women & & & Comparis & n referent & & \\
\hline Comparison outcomes & Father & Mother & $\begin{array}{l}\text { Male } \\
\text { friend }\end{array}$ & $\begin{array}{l}\text { Female } \\
\text { friend }\end{array}$ & $\begin{array}{l}\text { Average } \\
\text { Italian } \\
\text { man }\end{array}$ & $\begin{array}{l}\text { Average } \\
\text { Italian } \\
\text { woman }\end{array}$ \\
\hline More time & 75.5 & 15.7 & 51.1 & 28.9 & 50.2 & 19.6 \\
\hline About the same time (ref. cat.) & 11.8 & 18.1 & 28.8 & 45.2 & 34.2 & 47.6 \\
\hline Less time & 12.7 & 66.2 & 20.1 & 25.9 & 15.5 & 32.8 \\
\hline$N$ & 695 & 695 & 695 & 695 & 695 & 695 \\
\hline
\end{tabular}


Detailed output of results presented in Table 1: logistic regressions of men's perceived fairness $(1=$ fair, $0=$ unfair $)$ on comparison referents and control variables

\begin{tabular}{|c|c|c|c|c|c|c|c|c|c|c|c|c|}
\hline \multirow[b]{3}{*}{ Dep. var.: perceived fairness } & \multicolumn{12}{|c|}{ Type of comparison } \\
\hline & \multicolumn{2}{|c|}{$\begin{array}{l}\text { Respondent vs. his } \\
\text { father }\end{array}$} & \multicolumn{2}{|c|}{$\begin{array}{l}\text { Respondent's partner } \\
\text { vs. his mother }\end{array}$} & \multicolumn{2}{|c|}{$\begin{array}{l}\text { Respondent vs. his } \\
\text { male friend }\end{array}$} & \multicolumn{2}{|c|}{$\begin{array}{l}\text { Respondent's partner } \\
\text { vs. his friend's wife }\end{array}$} & \multicolumn{2}{|c|}{$\begin{array}{c}\text { Respondent vs. } \\
\text { average Italian man }\end{array}$} & \multicolumn{2}{|c|}{$\begin{array}{c}\text { Respondent's partner } \\
\text { vg. average Italian } \\
\text { woman }\end{array}$} \\
\hline & Coef. & Std. Err. & Coef. & Std. Err. & Coef. & Std. Err. & Coef. & Std. Err. & Coef. & Std. Err. & Coef. & Std. Err. \\
\hline \multicolumn{13}{|l|}{ Comparison outcomes } \\
\hline More time & -0.282 & 0.282 & -0.377 & 0.267 & 0.313 & $0.185+$ & -0.250 & 0.185 & 0.560 & $0.184^{* *}$ & -0.181 & 0.187 \\
\hline Less time & -0.833 & $0.412^{8}$ & 0.020 & 0.192 & -0.695 & $0.273^{8}$ & 0.049 & 0.234 & -0.578 & $0.284^{8}$ & -0.121 & 0.250 \\
\hline \multicolumn{13}{|l|}{ (Ref. cat: about the same time) } \\
\hline Respondent's \% of housework & 0.041 & $0.007^{* *}$ & 0.040 & $0.007^{* * *}$ & 0.035 & $0.007^{* * *}$ & 0.040 & $0.007^{* * *}$ & 0.033 & $0.007^{* * *}$ & 0.040 & $0.007^{* * *}$ \\
\hline Respondent's \% of childcare & 0.012 & $0.007+$ & 0.014 & $0.007^{8}$ & 0.014 & $0.007^{8}$ & 0.013 & $0.007^{*}$ & 0.015 & $0.007^{*}$ & 0.014 & $0.007^{8}$ \\
\hline Gender ideology & 0.013 & 0.108 & 0.029 & 0.108 & 0.016 & 0.108 & 0.018 & 0.107 & 0.026 & 0.109 & 0.022 & 0.107 \\
\hline Hours of paid work & -0.015 & $0.009+$ & -0.016 & $0.009+$ & -0.010 & 0.009 & -0.016 & $0.009+$ & -0.011 & 0.009 & -0.015 & $0.009+$ \\
\hline Age & -0.045 & $0.016^{* *}$ & -0.045 & $0.016^{* *}$ & -0.043 & $0.016^{* *}$ & -0.049 & $0.016^{* *}$ & -0.047 & $0.016^{* *}$ & -0.047 & $0.016^{8 *}$ \\
\hline Years of education & -0.093 & $0.031 * *$ & -0.091 & $0.031^{* *}$ & -0.078 & $0.030 * *$ & -0.079 & $0.029 * *$ & -0.090 & $0.030 * *$ & -0.080 & $0.029 * *$ \\
\hline Partner's hours of paid work & 0.005 & 0.009 & 0.004 & 0.009 & 0.003 & 0.009 & 0.004 & 0.009 & 0.002 & 0.009 & 0.004 & 0.009 \\
\hline Partner's years of education & 0.016 & 0.032 & 0.009 & 0.032 & 0.012 & $0.032^{8}$ & 0.011 & 0.032 & 0.002 & 0.032 & 0.014 & 0.032 \\
\hline Hours of paid domestic help & 0.012 & $0.007+$ & 0.012 & $0.007+$ & 0.014 & 0.007 & 0.014 & 0.007 & 0.013 & $0.007+$ & 0.014 & $0.01+$ \\
\hline Father's years of education & 0.031 & 0.025 & & & & & & & & & & \\
\hline Father's geographical origin (South) & -0.249 & 0.214 & & & & & & & & & & \\
\hline Mother's years of education & & & 0.029 & 0.028 & & & & & & & & \\
\hline Mother's geographical origin (South) & & & -0.115 & 0.212 & & & & & & & & \\
\hline Constant & 1.836 & $1.105+$ & 1.650 & 1.090 & 1.364 & 1.091 & 1.924 & $1.083+$ & 1.861 & $1.097+$ & 1.717 & 1.078 \\
\hline N cases & 684 & & 684 & & 684 & & 684 & & 684 & & 684 & \\
\hline Pseudo R2 & 0.11 & & 0.10 & & 0.11 & & 0.10 & & 0.12 & & 0.10 & \\
\hline Log likelihood & -419 & & -420.5 & & -415.0 & & -421.3 & & -413.0 & & -422.0 & \\
\hline
\end{tabular}

$+: p$ value $<0.1 ; *$ : $p$ value $<0.05 ;{ }^{* *}: p$ value $<0.01{ }^{* * *}: p$ value $<0.001$

Detailed output of results presented in Table 1: logistic regressions of women's perceived fairness $(1=$ fair, $0=$ unfair $)$ on comparison referents and control variables 


\begin{tabular}{|c|c|c|c|c|c|c|c|c|c|c|c|c|c|c|c|c|c|}
\hline \multirow[b]{3}{*}{ Dep. var.: perceived faimess } & \multicolumn{17}{|c|}{ Type of comparison } \\
\hline & \multicolumn{3}{|c|}{$\begin{array}{l}\text { Respondent vs. her } \\
\text { mother }\end{array}$} & \multicolumn{2}{|c|}{$\begin{array}{l}\text { Respondent's partmer } \\
\text { vs. her father }\end{array}$} & \multicolumn{3}{|c|}{$\begin{array}{l}\text { Respondent vs. her } \\
\text { female friend }\end{array}$} & \multicolumn{3}{|c|}{$\begin{array}{l}\text { Respondent's } \\
\text { partner vs. her } \\
\text { friend's husband }\end{array}$} & \multicolumn{3}{|c|}{$\begin{array}{l}\text { Respondent vs. } \\
\text { average Italian } \\
\text { woman }\end{array}$} & \multicolumn{3}{|c|}{$\begin{array}{l}\text { Respondent's } \\
\text { partner vs. average } \\
\text { Italian man }\end{array}$} \\
\hline & Coef. & Std. Enr. & & Coef. & Std. Err. & Coef. & Std. Er & & Coef. & Std. En & & Coef. & Std. Enr. & & Coef. & Std. Enr. & \\
\hline \multicolumn{18}{|l|}{ Comparison outcomes } \\
\hline More time & -0.208 & 0.283 & & -0.021 & 0.256 & -0.294 & 0.190 & & 0.030 & 0.190 & & 0.036 & 0.216 & & 0.519 & 0.185 & ** \\
\hline $\begin{array}{l}\text { Less time } \\
\text { (Ref. cat: about the same time) }\end{array}$ & -0.305 & 0.221 & & -0.767 & $0.325 *$ & -0.238 & 0.198 & & -0.627 & 0.231 & $8 *$ & -0.188 & 0.190 & & -0.027 & 0.242 & \\
\hline Respondent's \% of housework & -0.015 & 0.006 & \& & -0.011 & $0.006+$ & -0.014 & 0.006 & \& & -0.011 & 0.006 & + & -0.016 & 0.006 & $8 *$ & -0.009 & 0.006 & \\
\hline Respondent's \% of childcare & -0.021 & 0.006 & $* * *$ & -0.020 & $0.006 * *$ & -0.021 & 0.006 & *** & -0.021 & 0.006 & ** & -0.021 & 0.006 & $* *$ & -0.019 & 0.006 & ** \\
\hline Gender ideology & -0.052 & 0.106 & & -0.055 & 0.106 & -0.049 & 0.105 & & -0.052 & 0.106 & & -0.055 & 0.106 & & -0.052 & 0.106 & \\
\hline Hours of paid work & -0.012 & 0.008 & & -0.010 & 0.008 & -0.011 & 0.008 & & -0.013 & 0.008 & & -0.011 & 0.008 & & -0.012 & 0.008 & \\
\hline Age & -0.014 & 0.017 & & -0.017 & 0.017 & -0.015 & 0.017 & & -0.017 & 0.017 & & -0.014 & 0.017 & & -0.016 & 0.017 & \\
\hline Years of education & 0.033 & 0.032 & & 0.028 & 0.032 & 0.030 & 0.031 & & 0.025 & 0.031 & & 0.030 & 0.031 & & 0.025 & 0.031 & \\
\hline Spouse's hours of paid work & 0.008 & 0.008 & & 0.008 & 0.008 & 0.008 & 0.008 & & 0.007 & 0.008 & & 0.009 & 0.008 & & 0.011 & 0.008 & \\
\hline Spouse's years of education & -0.053 & 0.028 & + & -0.045 & 0.028 & -0.056 & 0.028 & 8 & -0.05 & 0.028 & + & -0.05 & 0.028 & + & -0.052 & 0.028 & + \\
\hline Hours of paid domestic help & 0.004 & 0.007 & & 0.004 & 0.007 & 0.003 & 0.007 & & 0.006 & 0.007 & & 0.004 & 0.007 & & 0.006 & 0.007 & \\
\hline Father's years of education & & & & -0.004 & 0.023 & & & & & & & & & & & & \\
\hline Father's geographical origin (South) & & & & -0.278 & 0.198 & & & & & & & & & & & & \\
\hline Mother's years of education & -0.003 & 0.025 & & & & & & & & & & & & & & & \\
\hline Mother's geographical origin (South) & -0.062 & 0.208 & & & & & & & & & & & & & & & \\
\hline Constant & 4.026 & 1.142 & \$** & 3.691 & $1.17 * * *$ & 3.892 & 1.120 & $* *$ & 3.817 & 1.146 & $8 *$ & 3.860 & 1.120 & $8 *$ & 2.982 & 1.154 & $*$ \\
\hline N cases & 695 & & & 695 & & 695 & & & 695 & & & 695 & & & 695 & & \\
\hline Pseudo R2 & 0.038 & & & 0.048 & & 0.039 & & & 0.047 & & & 0.037 & & & 0.046 & & \\
\hline Log likelihood & -448.4 & & & -443.5 & & -448.0 & & & -444.1 & & & -448.8 & & & -444.8 & & \\
\hline
\end{tabular}

$+: p$ value $<0.1 ;{ }^{*}: p$ value $<0.05 ;{ }^{* *}: p$ value $<0.01^{* * *}: p$ value $<0.001$

\section{Notes}

In a gender-unequal country like Italy (see its position in the European Union Gender Equality Index put forward by Plantenga et al. 2009) the ideal of supermom is likely to be popular even nowadays. As comparative research (Braun et al., 2008; T. N. Greenstein 2009; Öun, 2013) has shown, in gender-unequal countries women perceive objective inequalities in the division of household labor to be less unfair than in egalitarian countries.

The studies by Hawkins et al. $(1995 ; 1998)$ have been the first trying to operationalize the concept of comparison referent, but actually failed to properly measure them. Consequently, they did not carry out the empirical test.

The strategy of participant recruitment was not declared in the studies by Mikula and colleagues (1998; 2009) and Himsel and Goldberg (2003), who refer in general terms to a convenience sample. Kluwer and colleagues (2002) recruited participants through midwives. The reason for the use of convenience samples, that inevitably lower the relevance of the findings, is that ad-hoc surveys are required to study the effect of comparison referents on housework fairness. This is due to the fact that no large representative survey includes specific questions on this topic.

We performed several robustness checks. We excluded the few 'more than fair' cases among men and 'less than fair' among women and performed logistic regressions of the dummy response variable. In addition, we performed ordered logistic regression where the dependent variable was a more detailed three-category variable: much more (less, for men) than fair, a bit more (little less, for men) than fair, fair. Substantive results were always identical.

Respondent's percentage of housework and childcare was estimated using answers to several questions about the frequency of housework and care tasks. For a reliability assessment of this kind of synthetic measures see Norman and Elliott (2015).

Although this causes a substantial drop in the number of cases, results do not differ substantially if we analyze all the valid cases for each separate regression. 
For reliability reasons, we did not ask respondents to report the number of hours devoted to housework by their partner, so we are not able to perform the same check on women's answers about their spouses' domestic behavior.

As in an experiment, the randomization of factors across respondents ensures that individual characteristics do not influence the average effect of vignette factors on judgments.

Within the analysis sample, $74 \%$ of respondents form household couples with other respondents and hence are not statistically independent units. In view of this fact, we made robustness checks of our findings by computing robust standard errors (adjusted for clustering within couples) and by randomly sampling one respondent per couple. We found no substantial differences (results not shown).

\section{References}

BERGER, J., WAGNER, D. G., and ZELDITCH, M. (1985), Introduction: Expectation States Theory: Review and Assessment. In J. Berger and M. Zelditch (eds.), Status, Rewards and Influence, San Francisco: Jossey-Bass, p. 1-72. BERGER, J., ZELDITCH, M., ANDERSON, B., and COHEN, B. P. (1972), Structural Aspects of Distributive Justice: A Status Value Formulation. In J. Berger, M. Zeldtich, and B. Anderson (eds.), Sociological Theories in Progress. Vol. 2, Boston: Houghton Mifflin, p. 119-146.

BERNSTEIN, M. and CROSBY, F. (1980) 'An Empirical Examination of Relative Deprivation Theory',Journal of Experimental Social Psychology, 16 (5), p. 442-456.

BRAUN, M., LEWIN-EPSTEIN, N., STIER, H., and BAUMGÄRTNER, M. K. (2008) 'Perceived Equity in the Gendered Division of Household Labour', Journal of Marriage and Family, 70 (5), p. 1145-1156.

BUUNK, B. P. and VANYPEREN, N. W. (1991) 'Referential Comparisons, Relational Comparisons, and Exchange Orientation: Their Relation to Marital Satisfaction', Personality and Social Psychology Bulletin, 17 (6), p. 709-717.

BUUNK, B. P., KLUWER, E. S., SCHUURMAN, M. K., and SIERO, F. W. (2000) 'The Division of Labor Among Egalitarian and Traditional Women: Differences in Discontent, Social Comparison, and False Consensus', Journal of Applied Social Psychology, 30 (4), p. 759-779.

CARRIERO, R. (2011) 'Perceived Fairness and Satisfaction with the Division of Housework Among Dual-Earner Couples in Italy', Marriage and Family Review, 47 (7), p. 436-458.

CHARLES, M. and GRUSKY, D. B. (2004) Occupational Ghettos: The Worldwide Segregation of Women and Men, Stanford, CA: Stanford University Press.

CRAIG, L. and MULLAN, K. (2011) 'How Mothers and Fathers Share Childcare: A Cross-National Time-Use Comparison', American Sociological Review, 76 (6), p. 834-861.

CROSBY, F. (1976) 'A Model of Egoistical Relative Deprivation',Psychological Review, 83 (2), p. 85-113.

DUNCAN, G. J. (2008) 'When To Promote, And When To Avoid, A Population Perspective',Demography, 45 (4), p. $763-784$.

ENANDER, V. (2011) 'Leaving Jekyll and Hyde: Emotion work in the context of intimate partner violence', Feminism \& Psychology, 21 (1), p. 29-48.

EUROPEAN COMMISSION (2014) 'Report on Progress on Equality between Women and Men in 2013. Retrieved from http://ec.europa.eu/justice/gender-equality/files/swd_2014_142_en.pdf'.

EUROSTAT (2015) 'Statistics Database Online. Retrieved from http://ec.europa.eu/eurostat/data/database'.

EVERTSSON, M. (2014) 'Gender Ideology and the Sharing of Housework and Child Care in Sweden',Journal of Family Issues 35 (7), p. 927-949.

FESTINGER, L. (1954) 'A Theory of Social Comparison Processes', Human Relations, 7 (2), p. 117-140.

FESTINGER, L. (1957) A Theory of Cognitive Dissonance, Stanford: Stanford University Press.

FESTINGER, L. (1999), Reflections on Cognitive Dissonance: 30 years later. In E. Harmon-Jones and J. Mills (eds.), Cognitive Dissonance: Progress on a Pivotal Theory in Social Psychology, Washington: APA, p. 381-385.

FINCH, J. (1987) 'The Vignette Technique in Survey Research',Sociology, 21 (1), p. 105-114.

FREUDENTHALER, H. and MIKULA, G. (1998) 'From Unfulfilled Wants to the Experience of Injustice: Women's Sense of Injustice Regarding the Lopsided Division of Household Labor', Social Justice Research, 11 
(3), p. 289-312.

GAGER, C. T. (1998) 'The Role of Valued Outcomes, Justifications, and Comparison Referents in Perceptions of Fairness Among Dual-Earner Couples', Journal of Family Issues, 19 (5), p. 622-648.

GANONG, L. H. and COLEMAN, M. (2005) 'Measuring Intergenerational Obligations', Journal of Marriage and Family, 67 (4), p. 1003-1011.

GANONG, L. H. and COLEMAN, M. (2006) 'Multiple Segment Factorial Vignette Designs', Journal of Marriage and Family, 68 (2), p. 455-468.

GAUNT, R. (2013) 'Breadwinning Moms, Caregiving Dads: Double Standard in Social Judgments of Gender Norm Violators', Journal of Family Issues, 31 (1), p. 3-24.

GREENSTEIN, T. N. (2009) 'National Context, Family Satisfaction, and Fairness in the Division of Household Labor', Journal of Marriage and Family, 71 (4), p. 1039-1051.

GREENSTEIN, T.N. (1996) 'Gender Ideology and Perceptions of the Fairness of the Division of Household Labor: Effects on Marital Quality', Social Forces, 74 (3), p. 1029-1042.

GREENWALD, A. G. (1976) 'Within-Subjects Designs: To Use or Not To Use?', Psychological Bulletin, 83 (2), p. 314-320.

GROTE, N. K., NAYLOR, K. E., and CLARK, M. S. (2002) 'Perceiving the Division of Family Work to be Unfair: Do Social Comparisons, Enjoyment and Competence Matter?', Journal of Family Psychology, 16 (4), p. 510-522.

GRUNOW, D., SCHULZ, F., and BLOSSFELD, H. (2012) 'What Determines Change in the Division of Housework Over the Course of Marriage?', International Sociology, 27 (3), p. 289-307.

HARMON-JONES, E., AMODIO, D.M., and HARMON-JONES, C. (2009), Action-Based Model of Dissonance: A Review, Integration, and Expansion of Conceptions of Cognitive Conflict. In M. P. Zanna (ed.), Advances in Experimental Social Psychology. Volume 41, Burlington: Academic Press, p. 119-166.

HAWKINS, A. J., MARSHALL, C. M., and MEINERS, K. M. (1995) 'Exploring Wives' Sense of Fairness about Family Work', Journal of Family Issues, 16 (6), p. 693-721.

HAWKINS, A. J., MARSHALL, C., and ALLEN, S. (1998) 'The Orientation Toward Domestic Labor Questionnaire: Exploring Dual-Earner Wives' Sense of Fairness about Family Work', Journal of Family Psychology, 12 (2), p. 244-258.

HIMSEL, A. J. and GOLDBERG, W. A. (2003) 'Social Comparisons and Satisfaction with the Division of Housework: Implications for Men's and Women's Role Strain', Journal of Family Issues, 24 (7), p. 843866.

HOCHSCHILD, A (1989) The Second Shift: Working Parents and the Revolution at Home, New York: Avon Books.

HORNE, C. (2003) 'The Internal Enforcement of Norms', European Sociological Review, 19 (4), pp. 335-343.

JASSO, G. (1990) 'Methods for the theoretical and empirical analysis of comparison processes',Sociological Methodology, 20, p. 369-419.

JASSO, G. (1999) 'How Much Injustice is There in the World? Two New Justice Indexes',American Sociological Review, 64 (1), p. 133-168.

KELLERHALS, J., COENEN-HUTHER, J., and MODAK, M. (1988) Figure de l'équité. La construction des normes de justice dans les groups, Paris: Press Universitaires de France.

KIMURA, K. and SHINOKI, M. (2007) 'Decision and Justification in the Social Dilemma of Recycling. I. A TwoStage Model of Rational Choice and Cognitive Dissonance Reduction', Riron to Hoho/Sociological Theory and Methods, 22 (1), p. 31-48.

KLUWER, E. S. (1998) 'Responses to Gender Inequality in the Division of Family Work: The Status Quo Effect', Social Justice Research, 11 (3), p. 337-357.

KLUWER, E. S., HEESINK, J. A. M., and VAN DE VLIERT, E. (2002) 'The Division of Labor Across the Transition to Parenthood: A Justice Perspective', Journal of Marriage and Family, 64 (4), p. 930-943.

KNEER, J., GLOCK, S., and RIEGER, D. (2012) 'Fast and not Furious? Reduction of Cognitive Dissonance in Smokers.', Social Psychology Quarterly, 43 (2), p. 81-91.

LAM, C. B., MCHALE, S. M., and CROUTER, A. C. (2012) 'The Division of Household Labor: Longitudinal Changes and Within-Couple Variation', Journal of Marriage and Family, 74 (5), p. 944-952.

LAROSSA, R. (1988) 'Fatherhood and Social Change', Family Relations, 34 (4), p. 451-457. 
LAVEE, Y. and KATZ, R. (2002) 'Division of Labour, Perceived Fairness, and Marital Quality: The Effect of Gender Ideology', Journal of Marriage and Family, 64 (1), p. 27-39.

LAYTE, R. (1998) 'Gendered Equity? Comparing Explanations of Women's Satisfaction with the Domestic Division of Labour', Work, Employment \& Society, 12 (3), p. 511-532

LEACH, C. W., SNIDER, N., and IYER, A (2002), Poisoning the Consciences of the Fortunate: The Experience of Relative Advantage and Support for Social Equality. In I. Walker and H. J. Smith (eds.), Relative Deprivation. Specification, Development, and Integration, Cambridge: Cambridge University Press, $p$. 136-163.

LOPEZ-CLAROS, A. and ZAHIDI, A. (2005) Women's Empowerment: Measuring the Global Gender Gap, Cologny/Geneva: World Economic Forum.

MAJOR, B. (1987), Gender, Justice, and the Psychology of Entitlement. In P. Shaver and C. Hendrick (eds.), Sex and Gender, Beverly Hills: Sage, p. 124-148.

MAJOR, B. (1993) 'Gender, Entitlement, and the Distribution of Family Labor',Journal of Social Issues, 49 (3), p. 141-159.

MERTON, R. K. and ROSSI, A. K. (1968), Contributions to the Theory of Reference Group Behavior. In R. K. Merton (ed.), Social Theory and Social Structure, New York: Free Press.

MIKULA, G. (1998) 'Division of Household Labor and Perceived Justice: A Growing Field of Research',Social Justice Research, 11 (3), p. 215-241.

MIKULA, G., SCHOEBI, D., JAGODITSCH, S., and MACHER, S. (2009) 'Roots and Correlates of Perceived Injustice in the Division of Family Work', Personal Relationships, 16 (4), p. 553-574.

MUTZ, D. (2011) Population-Based Survey Experiments, Princeton, New Jersey: Princeton University Press.

NORDENMARK, M. and NYMAN, C. (2003) 'Fair or Unfair. Perceived Fairness of Household Division of Labour and Gender Equality among Women and Men: The Swedish Case ', The European Journal of Women's Studies, 10 (2), p. 181-209.

NORMAN, H. and ELLIOT, M. (2015) 'Measuring Paternal Involvement in Childcare and Housework', Sociological Research Online, 20 (2), p. 7.

ÖUN, I. (2013) 'Is it Fair to Share? Perceptions of Fairness in the Division of Housework Among Couples in 22 Countries', Social Justice Research, 26 (4), p. 400-421.

PERALES, FRANCISCO, BAXTER, JANEEN, and TAI, TSUI-O (2015) 'Gender, justice and work: A distributive approach to perceptions of housework fairness', Social Science Research, 51, p. 51-63.

PLANTENGA, J., REMERY, C., FIGUEIREDO, H., and SMITH, M. (2009) 'Towards a European Union Gender Equality Index', Journal of European Social Policy, 19 (1), p. 19-33.

ROESE, N. J. and OLSON, J. M (2007) 'Better, Stronger, Faster Self-Serving Judgment, Affect Regulation, and the Optimal Vigilance Hypothesis', Perspectives on Psychological Science, 2 (2), p. 124-141.

RUNCIMAN, W. G. (1966) Relative deprivation and social justice, Berkeley: University of California Press.

RUPPANNER, L. E. (2008) 'Fairness And Housework: A Cross-National Perspective',Journal of Comparative Family Studies, 39 (4), p. 509-526.

SARACENO, C. (2010) 'Social Inequalities in Facing Old-Age Dependency: A Bi-Generational Perspective', Journal of European Social Policy, 20 (1), p. 32-44.

SHEPELAK, N. J. and ALWIN, D.F. (1986) 'Beliefs about Inequality and Perceptions of Distributive Justice', American Sociological Review, 51 (1), p. 30-46.

TAYLOR, S. E., WAYMENT, H. A., and CARRILLO, M. (1996), Social Comparison, Self-Regulation, and Motivation. In R. M. Sorrentino and E. T. Higgins (eds.), Handbook of Motivation and Cognition, New York: Guilford, p. 3-27.

THOMPSON, L. (1991) 'Family Work: "Women's Sense of Fairness"', Journal of Family Issues, 12 (2), p. 181196.

WALLANDER, L. (2009) '25 Years of Factorial Surveys in Sociology: A Review',Social Science Research, 38 (3), p. 505-520.

WOOD, J. V. (1989) 'Theory and Research Concerning Social Comparisons of Personal Attributes', Psychological Bulletin, 106 (2), p. 231-248.

YOUNG, M., WALLACE, J. E., and POLACHEK, A. J. (2015) 'Gender Differences in Perceived Domestic Task Equity: A Study of Professionals', Journal of Family Issues, 36 (13), p. 1751-1781 
